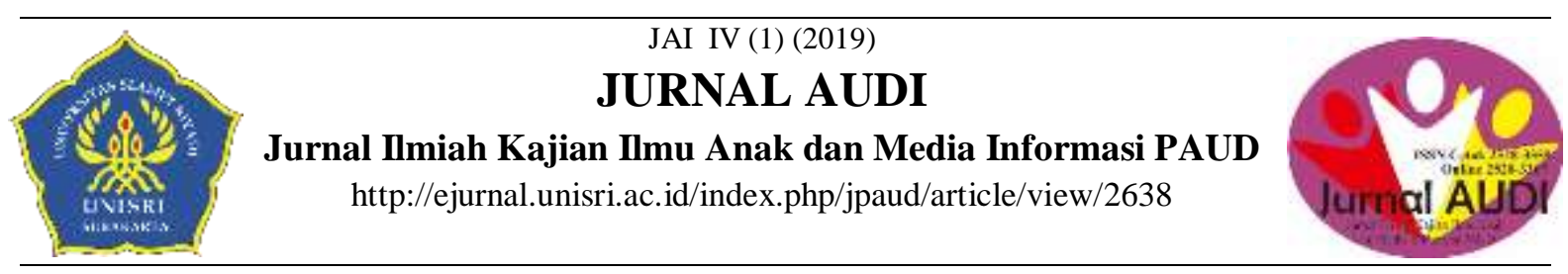

\title{
PEMBENTUKAN KARAKTER BERBASIS KEARIFAN LOKAL PADA ANAK USIA TK
}

\author{
Ashar $^{1}$, Endang Ruswiyani ${ }^{2}$ \\ PG_PAUD Universitas Islam Makassar
}

Info Artikel

Sejarah Artikel:

Diterima Januari 2019

Disetujui Mei 2019

Dipublikasikan

Juni 2019

Keywords:

Shape of character, game of local wisdom

\begin{abstract}
Abstrak
Tujuan penelitian ini membentuk karakter pada anak usia TK dengan melalui kegiatan berbasis permainan kearifan lokal. Penelitian ini merupakan penelitian deskriptif kualitatif. Hasil penelitian menunjukkan membentuk karakter anak didik di TK membutuhkan proses dan kerjasama antara pendidik dan keluarga, untuk itulah pendidik di sekolah membangun komunikasi efektif dengan keluarga anak didik yang memiliki peran yang sangat besar untuk membentuk karakter anak. Anak didik di TK dengan konsep bermain sambil belajar, sehingga upaya-upaya membentuk karakter yang dilakukan dengan bermain. Bermain kearifan lokal membentuk karakter anak usia TK dengan melalui permainan tumbu-tumbu lai'ya, maggulaceng, mabbelle, mammini, kaje-kaje capeng kaluku, manggunrecce, dan ular naga. Bentuk karakter anak didik di TK diataranya Kecintaan terhadap Tuhan YME, kejujuran, disiplin, toleransi dan cinta damai, percaya diri, mandiri, tolong menolong, kerjasama, dan gotong royong, hormat dan sopan santun, tanggungjawab, kerjakeras.
\end{abstract}

\section{Abstract}

The aim of this research is to characterize the kindergarten student through the activities of local wisdom game. The method of this research is a qualitative descriptive research. The results show that forming the character of the students in kindergarten requires the process and cooperation between the educator and the family, for which the educator in the school build an effective communication with the family of the students who have a very big role to shape the character of the child. Students in kindergarten with the concept of playing while learning, therefore, efforts to shape the characters were done by playing. Playing local wisdom to form the character of kindergarten through game of tumbu-tumbu lai'ya, maggulaceng, mabbelle, mammini, kaje-kaje kaluku kaluku, manggunrecce, and snake dragon. The shape of the character of kindergarten namely the love of God, honesty, discipline, tolerance and peacefully, confident, independent, mutually help, cooperation, and mutual cooperation, respect and courtesy, responsibility, hard working..

(C) 2019 Universitas Slamet Riyadi 


\section{PENDAHULUAN}

Pentingnya pembentukan karakter pada usia TK, dengan alasan bahwa anak usia TK merupakan mutlak mendapatkan perlakuan dari lingkungan keluarga dan lingkungan di sekolah. Anak didik tersebut sangat peka terhadap segala perlakuan yang diterimah dan disimpang dalam memorinya, oleh sebab itu segala perlakuan diperlukan pendekatan berbasis kearifan lokal, agar dapat membentuk damfak Positif terhadap perkembangan anak, baik pada nilainilai agama dan moral, sosial emosional serta kemandirian.

Menurut Hidayatullah (2010:13) menyatakan bahwa "karakter adalah kualitas atau kekuatan mental atau moral, akhlak atau budi pekerti individu yang merupakan kepribadian khusus yang menjadi pendorong atau penggerak, serta yang membedakan dengan individu lain. Lainnya Menurut Muslich (2011: 71) karakter memiliki dua pengertian yaitu menunjukkan bagaimana orang bertingkah laku dan berkaitan dengan personaliti. Berkaitan dengan seorang yang bertingkah laku, jika seseorang bertingkah laku baik seperti suka menolong, jujur, menunjukkan karakter mulia dan ini berlaku pula sebaliknya. Penanaman nilai pendidikan karakter pada anak usia dini sesuai PP No.58 suplemen kurikulum mencakup empat aspek yaitu aspek spiritual, aspek personal, aspek sosial dan aspek lingkungan.

Selanjutnya, karakter anak jika tidak dibentuk pada usia TK, maka dapat diakibatkan berbagai potensi dapat berkembang diantaranya melemahnya nilai-nilai agama dan moral, rendahnya rasa sosial, rendahnya tanggungjawab terhadap diri sendiri, ketidakjujuran, kekerasan meningkat, rendahnya perilaku-perilaku rasa hormat terhadap masyarakat.
Menurut Prasetyo (2011) menyatakan bahwa pendidikan karakter, setiap anak memiliki potensi untuk berperilaku posistif atau negatif. Jika ibu-ayah membentuk karakter positif sejak usia dini, maka yang berkembang adalah perilaku positif tersebut. jika tidak, tentu yang akan terjadi sebaliknya.

Pendidikan merupakan hak anak sebagaimana diatur dalam Undangundang No. 23 Tahun 2002 tentang Perlindungan Anak yang menyatakan bahwa "setiap anak berhak untuk hidup, tumbuh, berkembang dan berpartisipasi secara wajar sesuai dengan harkat dan martabat kemanusiaan, serta mendapat perlindungan dari hal-hal yang bersifat kekerasan dan diskriminasi". Salah satu implementasi dari hak anak adalah setiap anak berhak memperoleh pendidikan dan pengajaran yang layak dalam rangka pengembangan pribadi dan tingkat kecerdasan anak sesuai dengan minat dan bakat anak. Selanjutnya Permendikbud No 23 tahun 2015 dinyatakan bahwa kegiatan penumbuhan budi pekerti dapat dilakukan melalui kemandirian peserta didik dalam membiasakan keteraturan dan pengulangan, yang dimulai sejak dari masa orientasi peserta didik baru, proses kegiatan ekstrakurikuler, intra kurikuler, sampai dengan lulus.

Pada dasarnya, anak belajar berdasar pada apa yang dilihat di sekitarnya. Oleh karena itu, dikatakan bahwa anak merupakan salah satu variabel yang perlu diperhatikan dalam memilih dan menggunakan pendekatan dalam pembelajaran. Indikatorindikator perkembangan tersebut akan menentukan tingkat kemampuan anak dalam membentuk karakter anak didik, yaitu anak mampu mengubah perilakunya secara bertahap berdasarkan kebiasaan-kebiasaan yang dilakukan sebagai pengalaman belajar 
bagi anak didik dan yang telah diajarkannya.

Berbasis kearifan lokal merupakan salah satu cara membentuk karakter anak didik yang lebih baik dilaksanakan di kelas atau di sekolah secara aman dan menyenangkan. Kearifan lokal yang diimplementasikan dalam setiap kegiatan pengembangan kompetensi, sehingga anak didik akan tertarik mengikuti kegiatan pembelajan. Pada prinsipnya kearifan lokal adalah mengamati karakter anak dalam setiap kegiatan pengembangan, dimana anak didik secara aktif dan lebih tertarik mengikuti kegitan pembelajaran sehingga secara tidak langsung anak didik terbiasa melakukan hal-hal yang baik dan terbentuk karakter.

Pendekatan berbasis kearifan lokal dapat menjawab permasalahan yang dialami orang tua, pendidik dan anak didik. Lingkungan keluarga dan lingkungan sekolah yang merupakan hulu dari segala permasalahan yang dapat muncul pada setiap individu. Kebiasaaan-kebiasaan positif di lingkungan sekolah dan lingkungan keluarga merupakan bahagian mendukung pembentukan karakter anak didik.

Menurut Rahyono (2009) menyatakan bahwa Faktor-faktor yang menjadikan pembelajaran dan pemelajaran kearifan lokal memiliki posisi yang strategis sebagai berikut: a). Kearifan lokal merupakan pembentuk identitas yang inheren sejak lahir. b). Kearifan lokal bukan sebuah keasingan bagi pemiliknya. c). Keterlibatan emosional masyarakat dalam penghayatan kearifan local kuat. d). Pembelajaran kearifan lokal tidak memerlukan pemaksaan. e). Kearifan lokal mampu menumbuhkan harga diri dan percaya diri. f). Kearifan lokal mampu meningkatkan martabat Bangsa dan Negara.
Menurut Sutarno (2008) menyatakan terdapat tiga macam model pembelajaran berbasis budaya sebagai berikut: a). Melalui permainan tradisional dan lagu-lagu daerah. b). Melalui cerita rakyat. c). Melalui penggunaan alat-alat tradisional.

\section{Tujuan Penelitian}

Tujuan membentuk karakter anak didik pada prinsipnya berbasis kearifan lokal, sehingga dapat memberikan perlakuan agar anak didik secara aktif dan lebih tertarik mengikuti setiap kegiatan sehingga secara tidak langsung anak didik aktif melakukan hal-hal yang baik dan terbentuk karakter.

\section{KAJIAN PUSTAKA \\ Fungsi Pendidikan Karakter}

Menurut Zubaedi (2011:18) menyatakan bahwa pendidikan karakter memiliki tiga fungsi utama sebagai berikut:

a. Fungsi pembentukan dan pengembangan potensi.

b. Fungsi perbaikan dan penguatan.

c. Fungsi penyaring. Pendidikan karakter berfungsi memilah budaya bangsa sendiri dan menyaring budaya bangsa yang bermartabat.

\section{Membentuk Karakter Sejak Usia Dini}

Menurut Prasetyo (2011) Proses membangun karakter pada anak juga ibarat mengukir atau memahat jiwa sedemikian rupa, sehingga"berbentuk" unik, menarik, dan berbeda antara satu dengan yang lain. Setiap orang memiliki karakter berbeda-beda. Ada orang yang berperilaku sesuai dengan nilai-nilai, ada juga yang berperilaku negatif atau tidak sesuai dengan nilai-nilai yang berlaku dalam budaya setempat (tidak/belum berkarakter atau "berkarakter" tercela). 
Menurut Muslich (2011: 75) menekankan tiga komponen karakter yang baik dan harus ditanamkan sejak dini yaitu moral knowing (pengetahuan tentang moral), moral feeling (perasaan tentang moral), dan moral action (perbuatan moral). Tiga komponen ini sangat diperlukan untuk dapat memahami, merasakan, dan mengerjakan nilai-nilai kebijakan.

Pendidikan karakter sejak usia dini memang penting karena seperti membangun pondasi sejak usia dini. Pentingnya pendidikan anak usia dini (PAUD) dalam mendukung keberhasilan pendidikan karakter, maka pemerintah menggiatkan untuk memperluas akses PAUD. Upaya tersebut dilakukan untuk dapat menjangkau hingga semua lapisan masyarakat, termasuk mendukung pendirian lembaga PAUD baru di desadesa yang belum memiliki PAUD (Nuryanto, dan Izzaty (2016)

Pendidikan anak usia dini dilihat dari nilai-nilai dapat dipandang sangat penting dikenalkan dan diinternalisasikan ke dalam perilaku sehari-hari Direktorat Pembinaan PAUD (2012) sebagai berikut a). Kecintaan terhadap Tuhan YME, b). Kejujuran, c). Disiplin, d). Toleransi dan cinta damai, e). Percaya diri, f) Mandiri, g). Tolong menolong, kerjasama, dan gotong royong, $h$ ). Hormat dan sopan santun, i).Tanggung jawab, j). Kerja keras, k). Kepemimpinan dan keadilan.

\section{METODE PENELITIAN}

Jenis penelitian ini menggunakan pendekatan kualitatif deskriptif.

Fokus penelitian pelaksanaan pembentukan karakter berbasis kearifan local yang terdapat di TK Wanua Waru sebagai beriku:

1. Membentuk karakter berbasis kearifan lokal dengan melalui permainan kearifan lokal bugis yang tidak dikenal lagi pada anak-anak usi TK diantaranya permainan tumbu-tumbu belanga, maggulaceng, mabbelle, mammini, kaje-keje capeng kaluku, Maggungrecce, ular naga.

2. Gambaran karakter anak yang dilihat tingkah laku diantaranya kecintaan terhadap tuhan YME, kejujuran, disiplin, toleransi dan cinta damai, percaya diri, mandiri, tolong menolong, kerjasama, dan gotong royong, hormat dan sopan santun, tanggung jawab, kerja keras. Teknik pengumpulan data yang digunakan wawancara, observasi dan dokumentasi. Kemudian dianalisis data dengan tahap-tahap yang digunakan untuk menganalisis data ialah reduksi data, display data, dan kesimpulan. Selanjutnya dilakukan teknik pemeriksaan dan keabsahan data.

\section{HASIL PENELITIAN \\ Bentuk Karakter Anak Usia TK Kecintaan terhadap Tuhan YME}

Kecintaan terhadap tuhan yang maha esa merupakan hal yang sangat penting untuk dibiasakan sejak usia dini sebagai dasar untuk menanamkan nilainilai agama dan moral, hal ini dapat dilakukan di lingkungan keluarga dan lingkungan sekolah. Pendidik dan orang tua anak bekerjasama mengembangkan kecintaannya terhadap tuhan yang maha esa yang dapat dilakukan dengan membiasakan anak mengucapkan Salam jika bertemu Pada usia TK anak sudah dibiasakan melaksanakan shalat berjamaah dan membaca doa-doa, agar kebiasaan-kebiasan tersebut dapat melekat pada dirinya hingga tua.

Selanjutnya membentuk kecintaan anak terhadap tuhan yang esa dengan melalui permainan kearifan lokal dengan memperkenalkan dan membiasakan anak melakukan bacaan 
do'a atau basmalah sebelum memulai kegiatan-kegiatan permainan kearifan lokal dan sesudah melakukan permainan. Setiap kegiatan-kegiatan kearifan lokal yang diterapkan dengan terlebih dahulu diperkenalkan cara memainkan, manfaat permainan, alat permainan dan membiasakan membaca do'a untuk melakukan kegiatan permainan tersebut.

Dongeng juga termasuk bagian dari kearifan lokal yang ternyata ampuh untuk meningkatkan nilai kecintaan Tuhan. Seperti yang diungkapkan Sidik dalam Journal of Nonformal Education bahwa dongeng CAS CIS CUS dapat meningkatkan kecintaan terhadap Tuhan yang mulanya $68,8 \%$ pada siklus I menjadi $75 \%$, dan pada siklus II 87 , 5\% (Nuryanto, 2017)

\section{Kejujuran}

Kejujuran merupakan salah satu karakter anak yang sangat penting dibiasakan pada diri anak. Kejujuran merupakan sebagai modal untuk menjaga hubungan personal dan hubungan sosial dalam masyarat, sehingga kejujuran memerlukan proses diteladani terutama bagi orang tua dan pendidik (guru di sekolah).

Membentuk kejujuran anak usia TK dengan menerapkan beberapa permainan kearifan lokal dengan cara, yang terlebih dahulu memperkenalkan jenis permainan, jumlah pemain dan cara memainkannya seperti permainan tumbu-tumbu laiyya (tumbu-tumbu belanga) yang dapat dimainkan dengan jumlah tiga hingga lima anak, maggulaceng (congklak) dimainkan hanya dua orang, mammini (lompat karet) dimainkan tiga hingga enam orang.

Disiplin merupakan mentaati aturan-aturan yang berlaku, sehingga sangat penting dibiasakan sejak usia dini dalam menanamkan kedisiplinan pada diri anak untuk berperilaku yang baik. Disiplin juga merupakan bentuk kesadaran diri pada anak dan tanggungjawab serta dapat bekerjasama dengan teman sebayanya. Disiplin dalam permainan kearifan lokal tentunya pemain harus mengikuti aturan-aturan dan langkah-langkah permainan, agar dapat bermain secara sempurna

Namun disiplin pada anak usia TK dibentuk dengan melalui permainanpermainan kearifan lokal yang memiliki nilai-nilai budaya yang belum dikenal oleh anak, sehingga diterapkan permainan seperti permainan tumbutumbu laiya yang membentuk kemampuan untuk memiliki kesadaran diri anak dalam memahami aturan permainan tumbu-tumbu laiya tersebut, serta membentuk sikap dan perilaku yang baik dalam bermain bersama dengan teman sepermainan.

Selain itu permainan mabbelle juga membentuk sikap yang antusias dalam memainkan permainan secara positif yang sesuai aturannya, sehingga dapat membangun kerjasama yang baik dalam melakukan permainan yang kompetitif. Selanjutnya permainan ular naga, membentuk kemampuan emosional dengan alasan bahwa permainan ini membutuhkan kerjasama dengan teman sepermainan ular naga. Permainan kaje-kaje capeng kaluku, juga membentuk kedisiplinan anak dalam memainkan ketika kaki mulai berpijak pada capeng kaluku maka tangan harus menarik tali yang kuat-kuat, agar pijakan semakin kuat untuk memainkan dengan sempurna. Namun pada dasarnya semua permainan kearifan lokal yang diterapkan dapat membentuk kemampuan disiplin dalam bermain.

\section{Toleransi dan cinta damai}

Toleransi merupakan kemampuan yang dimiliki untuk saling menghargai 
sesama mahluk, sehingga sikap toleransi dibiasakan pada anak didik untuk menghindari terjadinya pertentangan secara fisik, agar tetap terjaga kebersamaan dan keutuhan dalam bermasyarakat. Toleransi dalam artian kemampuan bekerjasama dan kemampuan saling berbagi serta kemampuan saling menghormati, sehingga tercipta kenyamanan dan kedamaian berbangsa serta bersukusuku.

\section{Percaya diri}

Setiap anak memiliki potensi tumbuh dan berkembang terutama kemampuan percaya diri, sehingga membutuhkan stimulasi dari orangtua dan pendidik (orang dewasa) dan kebebasan berekspresi untuk membentuk rasa percaya dirinya. Percaya diri merupakan kemampuan melakukan tindakan-tindakan dengan penuh kreativitas dan kemampuan mengambil suatu keputusan serta kemampuan bermain bersama-sama. Anak tumbuh dan berkembang dari lingkungan hidupnya, tentunya membentuk rasa percaya diri anak dilakukan dengan permainan kearifan lokal.

Kearifan lokal

dapat mengespresikan perilaku anak dengan melalui beberapa permainan kearifan lokal yang diterapkan, sehingga permainan tersebut membentuk rasa percaya diri anak dalam memainkan dan menimbulkan kesenangan. Kebiasaan anak melakukan permainan dengan memiliki rasa percaya diri dalam memilih jenis permainan yang disukai dan membentuk sikap anak yang tidak mudah menyerah dalam memainkan, sehingga anak menjadi lebih tangguh. Tangguh dalam artian anak memiliki kemampuan tidak mudah menyerah dalam menghadapi kesulitan dan mudah menyesuaikan diri dengan lingkungannya serta selalu berbuat sesuatu, sehingga pada dasarnya beberapa permainan kearifan lokal membentuk kebiasaan anak memiliki kemampuan rasa percaya diri.

\section{Mandiri}

Kemandirian pada anak usia TK tentunya berbeda dengan kemandirian orang dewasa. Kemandirian orang dewasa yang meliputi memiliki kemampuan melakukan tugas dan tanggungjawab tanpa bantuan orang lain, sedangkan kemandirian pada anak usia TK yang tentunya sesuai tahap perkembangannya diantaranya mandi sendiri, memakai baju sendiri, makan sendiri, melaksanakan kegiatan sendiri sampai selesai, memeliharan mainan sendiri, mengembalikan mainan sendiri setelah digunakan.

Membentuk kemandirian anak usia TK yang tentunya membutuhkan proses yang dapat dimulai dari kebiasaankebiasaan melakukan sendiri. Kebiasaan dapat diterapkan dilingkungan keluarga dan sekolah untuk melatih kemandirian dari sejak usia TK untuk menjadi pribadi yang tangguh dan memiliki rasa bertanggungjawab hingga usia lanjut. Selain kebiasaan, dukungan dari lingkungannya yang sangat diharapkan untuk membentuk kemandirian anak, maka dari itu dilakukan permainan kearifan lokal untuk membentuk sikap mandiri. Permainan kearifan lokal seperti kaje-kaje capeng yang memiliki nilai budaya pada anak dengan menimbulkan kesenangan bermain dengan tertawa dan berteriak-teriak.

Permainan tersebut dilakukan dengan sendiri-sendiri sampai selesai. Selain itu, permainan maggulaceng juga membentuk sikap mandiri karena permainan ini berjumlah dua anak untuk memainkan secara berkompetensi sehingga berkembang kemampuan mengambil keputusan dalam 
memainkan dan tidak mudah putus asa. Selanjutnya permainan mabbelle membentuk anak menjadi tangguh dalam memainkan karena permianan ini harus melompak dengan mengangkat kaki satu untuk melewati garis kotakkotak yang ditentukan. Begitupula permainan mammini juga harus melompat untuk melewati bentangan karet dengan melakukan sendiri, sehingga bisa lebih tanggguh.

Tolong menolong, kerjasama, dan gotong royong

Tolong menolong pada anak usia dini merupakan bentuk sikap kepedulian sesama teman sebayanya dalam kehidupan sehari-hari. Sikap kepedulian itulah yang perlu dibekali anak sejak usia dini melalui stimulasi dari lingkungan sekitarnya, agar anak memiliki sikap peduli sesamanya dan lebih utama pada diri sendiri. Kemampuan kerjasama pada anak usia dini dapat dikatakan kemampuan bermain bersama seperti yang diketahui bahwa anak usia dini bermain sambil belajar. Kemampuan bermain bersama merupakan bentuk sikap sosial anak yang ditunjukkan dalam kegiatan bermain bersama, hal ini merupakan kerjasama anak dalam bermain. Kemampuan gotong royong pada anak usia dini yang dikenal bahwa kemampuan untuk menyelesaikan sesuatu yang dimaknai kemampuan menyelesaikan permainan dan kemampuan memiliki kepedulian pada lingkungan yang dilaksanakan secara bersama-sama.

Membentuk kemampuan tolong menolong, kerjasama, gotong royang yang dilakukan dengan permainan kearifan lokal seperti permainan kajekaje capeng kaluku memiliki nilai budaya yang dapat membiasakan anak didik membentuk kemampuan tolong menolong misalnya anak didik yang sudah mampu menggunakan kaje-kaje capeng kaluku yang sesuai aturannya dapat memberikan pertolongan kepada anak lainnya yang belum mampu menggunakan secara sempurna, sehingga kebiasaan itu membentuk kepedulian anak sesamanya.

Selanjutnya permainan tumbutumbu lai'ya, permainan maggulaceng, permainan mammini, permainan maggurecce, dan permainan mabbelle yang merupakan permainan kearifan lokal yang membutuhkan kerjasama bermain, sehingga memiliki nilai budaya yang dapat membiasakan anak didik bermain bersama dan menimbulkan kesenangan. Lainya permainan ular naga merupakan permainan yang memiliki nilai budaya yang harus bergotong royong, bekerjasama, tolong menolong dalam memainkan, sehingga permianan kearifan lokal ini membentuk kebiasaan anak didik memiliki kemampuan sosial dalam lingkungnnya.

\section{Hormat dan sopan santun}

Kemampuan hormat dan sopan santun pada anak usia TK sama halnya kemampuan menghargai dan kemampuan memiliki sikap dan perilaku yang baik (disiplin). Hal tersebut dapat terbentuk dengan adanya keteladanan dari lingkungan keluarga dan lingkungan sekolah.

Permainan kearifan lokal dapat membantu anak didik dalam mengembangkan berbagai potensi yang dimiliki, sehingga diterapkan berbagai permainan kearifan lokal yang memiliki nilai budaya dan disesuaikan tingkat perkembangannya dalam stimulasi kemampuan anak didik.

Membentuk kemampuan hormat dan sopan santun pada anak didik dilakukan dengan kebisaan bermain kearifan lokal. Bermain kearifan lokal dapat membentuk secara alami 
kemampuan hormat dan sopan santun anak didik. Kebiasaan bermain kearifan lokal seperti bermain mabbelle, maggunrecce, mammini, maggulaceng yang merupakan permainan berkompetesi yang memiliki nilai budaya membentuk rasa hormat kepada anak didik yang memiliki keunggulan dan membentuk sikap dan perilaku saling menghargai sesama teman.

\section{Tanggungjawab}

Nilai tanggungjawab sangat perlu dibekali sejak usia dini yang merupakan sebagai bekal yang dapat diaplikasikan dalam kehidupan sehari-hari. Sikap tanggungjawab itulah juga merupakan sebagai bentuk kemandirian anak untuk menjalani kehidupannya kelak dewasa. Tanggungjawab pada anak dapat dibentuk dengan berbagai upaya yang bisa dilakukan oleh orang-orang dilingkungan sekitarnya atau orang dewasa. Nilai tanggungjawab dapat diwujudkan dilingkungan anak yang dimulai dari hal-hal yang kecil misalnya diteladani menyimpan sampah pada tempatnya, kemudian dibiasakan untuk melakukan sendiri.

\section{Kerja keras}

Bentuk kerja keras anak didik di TK memilik keuletan dan penuh semangat dalam melakukan kegiatankegiatan bermain kearifan lokal seperti permainan mabbelle, mammini yang memiliki nilai kearifan lokal, membentuk anak didik memiliki kemampuan fisik motorik dalam melakukan aktivitas-aktivitas gerakan tubuh yang terkoordinasi dalam memainkan permainan tersebut dengan melompat satu kaki untuk melewati batas yang sudah ditentukan. Selanjutnya, membentuk kemampuan anak didik yang bersungguh-sunggu dan tidak mudah menyerah dalam menyelesaikan aktivitas bermain kearifan lokal sampai selesai. Selain itu, permainan kaje-kaje capeng kaluku juga sangat menarik dimaiman oleh anak didik yang memiliki nilai kearifan lokal, membentuk kemapuan kerja keras dan kematangan fisik anak didik dalam memainkan permainan, dengan melakukan pijakan kedua kaki di atas capeng kaluku sambil menarik tali untuk berjalan dengan menggunakan kaje-kaje capeng kaluku.

\section{PEMBAHASAN}

Bentuk karakter anak usia TK, sudah terbiasa membaca doa dalam melakukan kegiatan bermain kearifan lokal dan menimbulkan kesenangan dalam memainkannya. Kebiasaanya dapat dilakukan secara berangsurangsur, agar dapat tertanam pada diri anak lebih dalam, sehingga kemanapun si anak pergi akan terbawah karakter kecintaanya terhadap tuhan yang maha esa yang sudah melekat pada dirinya.

Bentuk kejujuran yang terbentuk melalui permainan kearifan lokal yang memiliki nilai budaya berperilaku jujur diantaranya

a. Permainan tumbu-tumbu laiyya, nilai kejujurannya pada setiap pemain dapat menunggu giliran untuk membuka kepalan tangan yang paling bawah setelah lagu tumbu-tumbu laiyya sampai selesai. Permainan ini membiasakan membentuk kesabaran dan keberanian untuk menunggu giliran membuka kepalan tangan sehingga dapat membentuk kejujuran saling percaya dan saling menghargai.

b. Permainan maggulaceng, memiliki nilai kejujuran yang tertanam pada diri anak ketika menjalankan permaina gulaceng karena setiap lubang-lubang kecil yang harus diisi satu persatu biji-bijian, sehingga permainan ini dapat membentuk 
kemampuan sportif untuk berkompetensi secara positif.

c. Permainan mammini, yang memiliki nilai budaya yang dapat membentuk kejujuran dalam permainan ketika misalnya pemegan karet harus membentang sesuai tahap demi tahap yang dimulai paling rendah ke yang paling tinggi. Permianan ini juga membentuk sportifitas dalam bermain, ketika pemain tidak mampu melewati karet yang dibentang maka pemain tersebut bergantian memegan karet.

Sikap toleransi pada anak dibentuk dengan permainan-permainan kearifan lokal yang diterapkan seperti tumbutumbu laiya, maggulaceng, mabbelle, mammini, kaje-kaje capeng, maggungrecce, ular naga. Setiap permainan yang dimainkan membentuk sikap toleransi pada anak diantaranya kemampuan bermain bersama-sama, kemampuan kepercayaan diri anak ketika pada saat bergantian memainkan permainan, memiliki kemampuan rasa hormat ketika teman bermain memiliki keunggulan atau memenangkan permainan dan mampu bekerjasama dalam setiap permainan. Hal ini merupakan sikap toleransi yang terbentuk yang terus dibiasakan agar terbawa hingga usia lanjut.

Metode pembelajaran toleransi TK Town For Kids Pontianak Tenggara menggunakan bermain, bercakapcakap, bercerita, demonstrasi, pemberian tugas, proyek, karya wisata (Santi Sipa, Purwanti, Dian Miranda.2016)

Bentuk kemandirian anak sudah terbentuk seperti mencuci tangan sendiri, makan sendiri, memakai sepatu sendiri, menyimpan tas sendiri yang telah disediakan, mengembalikan mainan sendiri. Melalui permainan kearifan lokal, anak menjadi lebih tangguh, tidak mudah menyerah, bertanggungjawab, mampu mengambil keputusan, dan memelihara lingkunga.

Terbentuknya kemampuan tolong menolong, kerjasama, dan gotong royong pada anak didik dengan melalui permainan kearifan lokal yang telah dilaksanakan. Kemampuan yang dimiliki tentunya memerlukan kebiasaan dan keteladanan secara berkesinambungan, agar tertanam lebih mendalam pada diri anak dan terbawa hingga dewasa. Kebiasaan yang tertanam pada diri anak dapat terbawa kemanapun si anak pergi, oleh sebab itu dengan adanya permainan kearifan lokal anak didik terbantu dalam pengembangan kemampuan kepedulian sesamanya.

Bentuk kemampuan anak usia TK dalam lingkungan sekolah, yang dibiasakan anak didik seperti saling menghargai, memberi salam dan membalas salam, selalu mengucapkan terima kasih jika memperoleh sesuatu dan menggunakan Bahasa-bahasa positif. Kemampuan hormat dan sopan santun pada anak didik yang harus diteladani sejak usia dini, diperhatikan, dibiasakan dan jangan dipaksakan. Kemampuan tersebut terbentuk dengan secara alami apa yang dilihat dan apa yang dirasakan, sehingga lingkungan yang paling utama membentuk kemampuan anak didik

Bentuk tanggungjawab anak didik yang merupakan kemampuan melakukan sendiri dan menyelesaikan sendiri. Aktivitas yang dilakukan anak usia TK di sekolah seraya bermain sambil belajar, yang secara sederhana bentuk tanggungjawab dibebankan ketika anak didik mampu menjaga mainan dan mengembalikan mainan setelah digunakan serta melaksanakan arahan-arahan. Sikap anak didik seperti itu, diasah dan dibiasakan melakukan aktivitas bermain sampai tuntas, sebagai 
bentuk perwujudan tanggungjawab terhadap sikap dan perilaku yang dimiliki anak didik.

Kerja keras pada anak usia dini merupakan kemampuan fisik dalam melakukan aktivitas yang secara bersungguh-sungguh dan tidak mudah putus asa. Aktivitas anak usia dini adalah kegiatan bermain dengan kemampuan fisik yang dimiliki untuk mendapatkan kesenangan dan kepuasan. Kemampuan kerja keras pada anak didik sangat penting dibentuk untuk menghapai berbagai tantangan kedepannya, kerja keras merupakan modal untuk meraih kesuksesan dimasa akan datang

\section{KESIMPULAN}

Membentuk karakter anak didik di TK membutuhkan proses dan kerjasama antara pendidik dan orangtua, untuk itulah pendidik di sekolah membangun komunikasi efektif dengan orang tua yang memiliki peran yang sangat besar untuk menumbuhkan karakter anak. Anak didik di TK dengan konsep bermain sambil belajar, sehingga upayaupaya membentuk karakter yang dilakukan dengan bermain. Bermain kearifan lokal dapat membentuk karakter anak usia TK dengan melalui permainan tumbu-tumbu lai'ya, maggulaceng, mabbelle, mammini, kaje-kaje capeng kaluku, manggunrecce, dan ular naga.

Bentuk karakter anak didik di TK diataranya Kecintaan terhadap Tuhan YME, kejujuran, disiplin, toleransi dan cinta damai, percaya diri, mandiri, tolong menolong, kerjasama, dan gotong royong, hormat dan sopan santun, tanggungjawab, kerjakeras.

\section{DAFTAR PUSTAKA}

Direktorat Pembinaan Pendidikan AnaUsia Dini. (2012). Pedoman Pendidikan Karakter pada Pendidikan Anak Usia Dini. Jakarta Gunawan, Heri. 2012. Pendidikan Karakter Konsep Dan Implementasi. Bandung: Alfabeta

Hasan, Said, Hamid. 2010. "Pengembangan Pendidikan Budaya dan Karakter Bangsa", Bahan Pelatihan Penguatan Metodologi Pembelajaran Berdasarkan Nilai- nilai Budaya untuk Membentuk Daya Saing dan Karakter Bangsa. Jakarta: Puskur Balitbang Kemendiknas.

Hidayatullah, Furqan. 2010. Pendidikan Karakter Membangun Peradaban Bangsa. Surakarta: Yuma Pustaka.

Muchlas dkk. 2011. Pendidikan Karakter Konsep Dan Model. Bandung: PT Remaja Rosdakarya. Muslich, Masnur. 2011. Pendidikan Karakter: Menjawab Tantangan Krisis Multidimensional. Jakarta: PT. Bumi Aksara

Nuraeni. 2014. Pendidikan Karakter Pada Anak Usia Dini. Jurnal Paedagogy Volume 1 Nomor 2 Edisi Oktober 2014 Fakultas Ilmu Pendidikan IKIP Mataram

Nuryanto, S., \& Izzaty, R. E. (2016). Peranan dongeng dalam pendidikan karakter pada taman kanak-kanak Lazuardi Kamila di Surakarta. JPPM (Jurnal Pendidikan dan Pemberdayaan Masyarakat), 3(1), 75-84.

Nuryanto, S. (2017). Peningkatan NilaiNilai Karakter Dengan Metode Mendongeng CAS CIS CUS Di BA Aisyiyah Kaponan 2 Ponorogo. Journal of Nonformal Education, 3(1), 11-20.

Permendikbud Nomor 23 Tahun 2015. Penumbuhan Budi pekerti 
Prasetyo, Nana. 2011. Membangun

Karakter Anak Usia Dini:

Direktorat Pembinaan Pendidikan

Anak Usia Dini Direktorat Jenderal

Pendidikan Anak Usia Dini

Nonformal dan Informal

Kementerian Pendidikan Nasional.

Rahyono. 2009. Kearifan Budaya

Dalam Kata. Jakarta: Wedatama Widya Sastra.

Sipa, S., \& Miranda, D. UPAYA GURU

MENUMBUHKAN SIKAP

TOLERANSI BAGI ANAK USIA

DINI. Jurnal Pendidikan dan

Pembelajaran, 5(06).
Sukmadinata, Nana Syaodih. 2009.

Metode Penelitian Pendidikan,

(Bandung: PT Remaja Rosdakarya.

Sutarno. 2008. Pendidikan

Multikultural. Jakarta: Direktorat

Jendral Pendidikan Tinggi

Departemen Pendidikan Nasional.

Tafsir, Ahmad. 2007. Ilmu Pendidikan

Dalam Perspektif Islam. Bandung:

PT Rosdakarya.

Zubaedi. 2011. Desain Pendidikan

Karakter: Konsepsi dan Aplikasi

Dalam Lembaga Pendidikan.

Jakarta: Kencana. 